\title{
Nitrogen limitation of North Atlantic phytoplankton: analysis of physiological condition in nutrient enrichment experiments
}

\author{
L. M. Graziano ${ }^{1, *}$, R. J. Geider ${ }^{1, * *}$, W. K. W. Li $^{2}$, M. Olaizola ${ }^{3, * * *}$ \\ 'College of Marine Studies, University of Delaware, Lewes, Delaware 19958, USA \\ ${ }^{2}$ Department of Fisheries and Oceans, Bedford Institute oi Oceanography, Dartmouth, Nova Scotia, Canada B2Y 4A2 \\ ${ }^{3}$ Joint Research Centre, Institute for Remote Sensing Applications, Marine Environment Unit, I-21020 Ispra (VA), Italy
}

\begin{abstract}
Nutrient enrichment experiments were conducted in May and June of 1993 at 8 stations along a North Atlantic transect, from Morocco to Nova Scotia, Canada. Variable fluorescence $\left(F_{\mathrm{v}} / F_{\mathrm{m}}\right)$ was measured in order to estimate the health or physiological state of the population as a whole. Low values across the transect indicated nutrient limited photosynthetic efficiency and probable growth rates ranging from 10 to about $50 \%$ of $\mu_{\max }$. Where the lowest value was measured, over the Grand Banks of Newfoundland, Canada, nitrogen addition to incubated samples resulted in large, significant increases in photochemical efficiency. Numbers and cell-specific fluorescence of 3 major groups of picophytoplankton were studied using flow cytometry, in order to further quantify the physiological response to nutrient additions. Results indicated nitrogen limitation of physiology and/or abundance of small eukaryotes, cyanobacteria, and prochlorophytes. Abundance (cell numbers) and cellular fluorescence of the 3 groups responded differently to nutrient additions. Prochlorophytes showed the greatest response to incubation in terms of cell numbers, responding especially to nitrogen addition. By contrast, cyanobacterial numbers did not change from initial values or with treatment, although cell pigment content did. Cellular fluorescence as measured by the flow cytometer reflected cell pigment content in most experiments. Increased cellular fluorescence of all groups in nitrogen-amended treatments relative to unamended controls indicated physiological limitation by nitrogen.
\end{abstract}

KEY WORDS: Nitrogen limitation Physiology Fluorescence

\section{INTRODUCTION}

Nutrient availability may affect phytoplankton productivity in 2 ways. First, fluxes of dissolved inorganic nutrients into, and organic nutrients out of, the euphotic zone may limit phytoplankton abundance (Dugdale \& Wilkerson 1992). Second, the concentra-

\section{Present addresses:}

- Bigelow Laboratory for Ocean Sciences, Mckown Point, West Boothbay Harbor, Maine 04575, USA.

E-mail: lgraziano@bigelow.org

- Marine Biological Association of the UK, The Laboratory, Citadel Hill, Plymouth PL1 2PB, United Kingdom

-.Marine Life Research Group, Scripps Institution of Oceanography, University of California at San Diego, La Jolla, California 92093-0218, USA. tion of inorganic nutrients may limit phytoplankton growth rate (Dugdale \& Goering 1967). The first type of limitation may be considered a modification of Liebig's Law of the Minimum while the second can be viewed as an extension of Blackman kinetics. The ability to distinguish between these 2 types of limitation has important implications for understanding oceanic productivity (Falkowski et al. 1992).

Diagnosis of nutrient limitation based on bioassay experiments is controversial and the application of concepts such as Liebig's Law is not straightforward (Cullen et al. 1992). For example, the absence of biomass accumulation following enrichment does not imply limitation of growth rate, due to complications arising from grazing and nutrient recycling (Goldman 1980). In addition, measurement of bulk parameters 
such as chlorophyll a (chl a) and cell numbers gives no information on physiological responses of a populatinn, or on the responses of different taxa within an assemblage.

Interpretation of nutrient addition experiments and in situ measurements may be aided by recently achieved abilities to observe physiological changes independently of biomass changes using rapid fluorescence techniques (Greene et al. 1991, 1994), and to efficiently quantify the responses of different phytoplankton taxa, on a single-cell basis, using flow cytometry (Legendre \& Yentsch 1989, DiTullio et al. 1993). Pump-and-probe and FRR (fast repetition rate) fluorometry provide measurements of variable fluorescence yield arising from photosystem II (Kolber et al. 1988, Kolber \& Faikowski i993j. Severdi siuủies hảve established that low variable fluorescence may be equated to low photochemical efficiency (Kolber \& Falkowski 1993). Variable fluorescence is directly related to the nutritional status of the cell (Kolber et al. 1988), although it may be affected by photoinhibition and photoadaptation (Geider et al. 1993a). A major advantage of this technique is that variable fluorescence has a physiological maximum achieved under nutrientreplete conditions, independent of the taxon under investigation, and therefore gives an absolute rather than a relative measure of photosynthetic efficiency. A disadvantage is that it provides a bulk population measurement, and does not distinguish among sub-populations which may respond differently to environmental conditions. Flow cytometry allows distinction amongst major taxonomic groups, based on size and fluorescence characteristics of individual cells (Legendre \& Yentsch 1989). This allows observation of both physiological (cell pigment content) and biomass (cell number) changes within several major taxa during incubation experiments.

Here we describe 8 experiments conducted across the North Atlantic, in which pump-and-probe fluorometry and flow cytometry were used to infer the relative physiological state or health of in situ populations, and to observe changes in cell physiology and total biomass in response to 8 different nutrient addition treatments. The major objectives were: (1) to directly measure physiological responses, as well as changes in cell numbers, of the phytoplankton to nutrient additions; (2) to separately quantify responses of the major taxonomic groups present; and (3) based on bioassay experiments and sampling of the water column, to infer in situ the physiological state of the North Atlantic phytoplankton populations. Our results indicate physiological limitation by nitrogen across much of the North Atlantic ocean.

\section{METHODS}

Eight stations were sampled in May and June of 1993 for nutrient addition experiments (Fig. 1). A balanced design was used to examine the effects of nitrogeñ, phosphorus, and iron (N, P, and Fe) alone and in
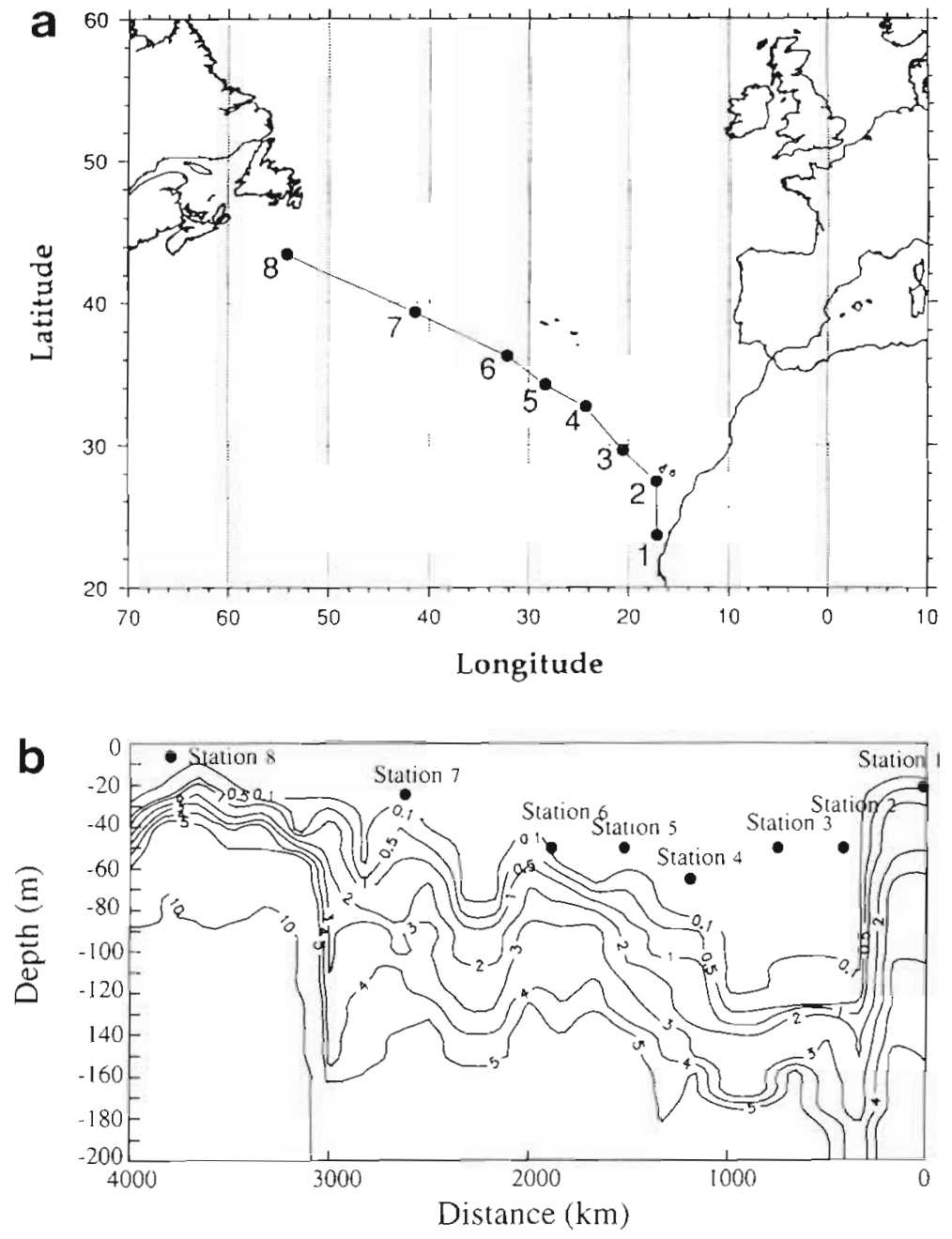

Fig. 1 (a) Cruise track of the CSS 'Hudson' May 21 to June 7, 1993, showing locations of stations where nutrient addition experiments were performed. (b) Nitrate contour plot, with stations indicated. Nitrate measurements courtesy W. G. Harrison and B. Irwin 
combination. To this end 8 treatments were employed, each in duplicate: additions of (1) $\mathrm{N}$ alone; (2) P alone; (3) Fe alone; (4) $\mathrm{N}$ and $\mathrm{P}$ together; (5) $\mathrm{N}$ and $\mathrm{Fe}$ together; (6) P and Fe together; (7) N, P, and Fe; and (8) a control treatment with no additions, to distinguish enclosure effects from effects of treatment. At each station, water was collected with two 10 l Go-Flo bottles (Wu \& Luther 1994) on Kevlar line at approximately 10:00 h local time, dispensed into trace-metal clean $500 \mathrm{ml}$ polypropylene bottles, and enriched in 1 or more nutrients. Exposure to surface irradiance was avoided during collection and all subsequent steps.

The trace-metal cleaning procedure for Go-Flo and polypropylene bottles involved a detergent wash followed by $50 \%$ nitric acid, followed by successive washes in decreasing $\mathrm{HCl}$ concentrations $(50,25,10$ and $5 \%$, and a final acid-soak in Ultima trace-metal clean $\mathrm{HCl}$. Polypropylene bottles were chosen because they are $100 \%$ translucent to light and are the cleanest plastic containers available, routinely used by tracemetal chemists for trace-element analyses.

Samples were incubated in flowing seawater ondeck incubators with light attenuated to either 4 or $10 \%$ of incident photosynthetically active radiation by blue plexiglass screening to approximate the in situ spectral quality. Incubations were carried out from approximately noon to noon to minimize potential diel variations in $F_{\mathrm{v}} / F_{\mathrm{m}}$ and fluorescence yield. Nitrogen, phosphorus, and/or iron were added alone or in combination to increase nutrient concentrations by 1 to 5 $\mu \mathrm{M} N, 0.05$ to $0.5 \mu \mathrm{M}$ P, and/or 2 or $4 \mathrm{nM}$ Fe. Table 1 summarizes the conditions of each experiment. A light meter was not available to measure irradiance at sam- ple depths, so this has been calculated (Table 1). Nitrate $(100 \mathrm{mM})$, ammonium $(100 \mathrm{mM})$, and phosphate $(10 \mathrm{mM})$ stock solutions contained less than $5 \mathrm{nM}$ Fe after treatment with chelex resin. Since these were added to seawater in dilutions of about 1 to 100000 , trace metal additions were negligible. Iron stock solutions $\left(10 \mu \mathrm{M} \mathrm{FeCl}_{3}\right)$ were prepared in $0.001 \mathrm{M} \mathrm{HCl}$. Samples were dispensed and nutrient additions performed in a class 100 clean bench.

Initial and final sampling. Duplicate $100 \mathrm{ml}$ samples were collected onto GF/F filters, extracted for $24 \mathrm{~h}$ at $-20^{\circ} \mathrm{C}$ in $90 \%$ acetone, and chlorophyll determined fluorometrically using a Turner Designs fluorometer calibrated against pure chl a (Strickland \& Parsons 1972). Samples for pump-and-probe fluorescence measurements were dark-adapted for at least $30 \mathrm{~min}$ and then concentrated onto GF/F filters at low light $\left(<50 \mu \mathrm{E} \mathrm{m} \mathrm{m}^{-2} \mathrm{~s}^{-1}\right.$ ) under gentle vacuum filtration (<10 mm Hg) (Olaizola \& Yamamoto 1994). Concentration was necessitated by the extremely low biomass. Filters were trimmed to fit into a $1 \mathrm{~cm}$ cuvette which contained a small amount of filtered seawater and measurements were generally completed within $2 \mathrm{~min}$ of filtration. Initial fluorescence of dark-adapted sample $\left(F_{0}\right)$, and maximum fluorescence following a saturating light flash $\left(F_{\mathrm{m}}\right)$, were determined with a custom built pump-and-probe fluorometer (Kolber et al. 1988). Standard deviations for averages of 10 data points $\left(F_{0}\right.$ or $F_{\mathrm{m}}$ ) varied between 0.2 and $8.0 \%$ for all data collected, with the majority of cases being $<4 \%$. A comparison of filtered sample with a cell suspension at a high biomass station gave the same average $F_{\mathrm{v}} / F_{\mathrm{m}}$ (data not shown).

Table 1 Nutrient addition experiments. Eight treatments in duplicate were incubated in each case, using either no addition (control, $=\mathrm{C}$ ) or phosphate, nitrate + ammonium, and iron singly or in combination ( $\mathrm{N}, \mathrm{P}, \mathrm{Fe}, \mathrm{NP}, \mathrm{NFe}, \mathrm{PFe}, \mathrm{All}$ ). Water column nutrient concentrations were measured by automated colorimetry within 1 h of sample collection

\begin{tabular}{|c|c|c|c|c|c|c|c|c|c|c|}
\hline \multirow[t]{2}{*}{$\operatorname{Stn}$} & \multirow[t]{2}{*}{ Hours } & \multirow{2}{*}{$\begin{array}{l}\text { Collection } \\
\text { depth } \\
(\mathrm{m})\end{array}$} & \multirow{2}{*}{$\begin{array}{l}\% \text { surface } \\
\text { irradiance }\end{array}$} & \multirow{2}{*}{$\begin{array}{l}\% \text { incubation } \\
\text { irradiance }\end{array}$} & \multicolumn{3}{|c|}{ Additions } & \multicolumn{3}{|c|}{ Ambient concentrations } \\
\hline & & & & & $\begin{array}{c}N^{b} \\
(\mu M)\end{array}$ & $\begin{array}{l}\mathrm{PO}_{4}^{3-} \\
(\mu \mathrm{M})\end{array}$ & $\begin{array}{c}\mathrm{Fe} \\
(\mathrm{nM})\end{array}$ & $\begin{array}{c}\mathrm{Chl}^{-} \\
\left(\mu \mathrm{g} \mathrm{l}^{-1}\right)\end{array}$ & $\begin{array}{l}\mathrm{SiO}_{2} \\
(\mu \mathrm{M})\end{array}$ & $\begin{array}{l}\mathrm{PO}_{4}{ }^{3-} \\
(\mu \mathrm{M})\end{array}$ \\
\hline 1 & 48 & 20 & 39 & 10 & 5.0 & 0.5 & 4.0 & 0.11 & 0.93 & 0.01 \\
\hline 2 & 24 & 50 & 10 & 10 & 5.0 & 0.5 & 4.0 & 0.10 & 0.22 & 0.05 \\
\hline 3 & 24 & 50 & 22 & 4 & 5.0 & 0.5 & 4.0 & 0.04 & 0.73 & 0.04 \\
\hline 4 & 48 & 65 & 8 & 4 & 2.0 & 0.1 & 2.0 & 0.07 & 0.50 & 0.01 \\
\hline 5 & 48 & 50 & 16 & 4 & 2.0 & 0.1 & 4.0 & 0.06 & 0.85 & 0.08 \\
\hline 6 & 48 & 50 & 16 & 4 & 1.0 & 0.05 & 2.0 & 0.06 & 0.36 & 0.10 \\
\hline 7 & 24 & 25 & 28 & 10 & 2.0 & 0.1 & 4.0 & 0.13 & 0.15 & 0.02 \\
\hline 8 & 24 & 5 & 62 & 10 & 5.0 & 0.5 & 4.0 & 0.59 & 0.30 & 0.54 \\
\hline \multicolumn{11}{|c|}{$\begin{array}{l}\text { Calculated using the chlorophyll concentration and Morel's }(1987) \text { Eq. }(5)\left[K_{\mathrm{PAR}}\left(0, Z_{\mathrm{e}}\right)=0.121 C^{0428} \text {, where } K_{\mathrm{PAR}} \text { is the mean }\right. \\
\text { attenuation coefficient for the euphotic zone of depth } Z_{\mathrm{e}} \text { and } C \text { is the mean pigment concentration]. The fraction of surface } \\
\text { downwelling irradiance was estimated by applying Smith \& Baker's }(1978) \text { Eq. (2) relating surface irradiance, E(0), to irradi- } \\
\text { ance at depth }\left[E(Z)=E(0) \mathrm{e}^{-(K T Z)} \text {, where } K T=K_{\mathrm{PAR}}\right]\end{array}$} \\
\hline \multicolumn{11}{|c|}{${ }^{\mathrm{C}} \mathrm{NO}_{3}{ }^{-}$concentration was $0.08 \mu \mathrm{M}$ at Stn 1 , but was below the detection limit of $0.05 \mu \mathrm{M}$ at all other stations } \\
\hline
\end{tabular}


Flow cytometry analyses were completed within $3 \mathrm{~h}$ of sampling using a FACSort (Becton Dickinson, New Jersey, USA) with a sample volume of 0.25 to $0.5 \mathrm{ml}$. Abundances of 4 groups of ultraplankton were distinguished based on size (forward angle light scatter, $<1$ to $\left.10^{\circ}\right)$, relative chl a $(>650 \mathrm{~nm}$, = 'red') fluorescence intensity, and phycoerythrin (585 $\pm 21 \mathrm{~nm}$, = 'orange') fluorescence (Li 1994, 1995). Particles with red fluorescence weaker than emitted by Prochlorococcus sp. were rejected, to insure that only phytoplankton were counted. Forward light scatter was recorded in relative units based on measurements of beads of different sizes and composition (Polysciences \#18859, 18860 , 18604, 18861, 18862; Duke Scientific \#R600, R0100, R0290, 268, 361; Coulter fluorosphere $5.43 \mu \mathrm{m}$; $8.55 \mu \mathrm{m}$, and $9.04 \mu \mathrm{m}$ ). The ınye of equivalent spherical diameter was from 0.44 to $6.8 \mu \mathrm{m}$. The groups distinguished were prochlorophytes (Prochlorococcus spp.), chroococcoid cyanobacteria, and eukaryotes showing low or high intensity light scatter (referred to as small and large euks). The small euks were shown. to pass through a $1 \mu \mathrm{m}$ polycarbonate membrane while the large euks were retained, although most passed through a 2 um membrane (Li 1994). Values are
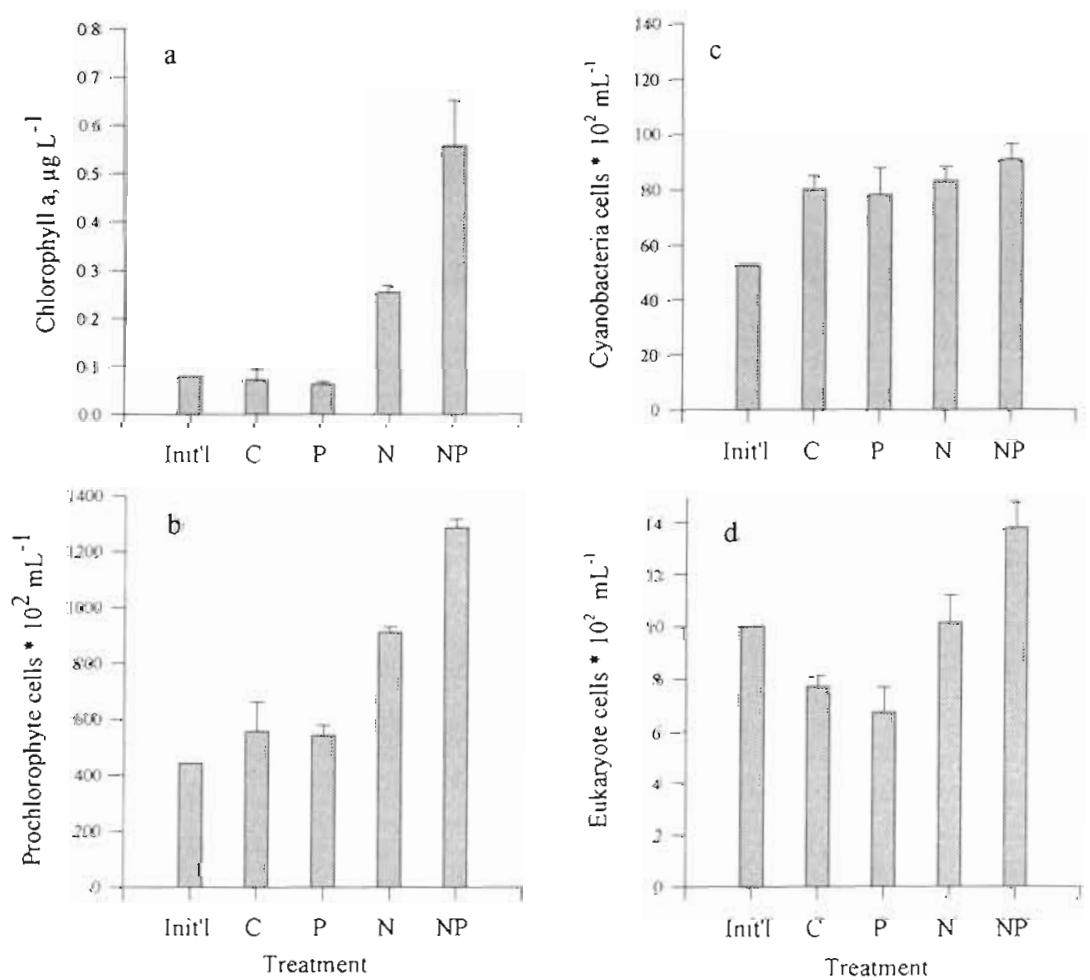

Fig. 2. Chlorophyll concentration and cell numbers from $\mathrm{Stn} 6$. (a) $\mathrm{Chl} \mathrm{a}_{\text {i }}$ (b) cells $\mathrm{ml}^{-1} \times 10^{2}$ of prochlorophytes; (c) cyanobacteria; and (d) eukaryotes; note change of scale. Mean $\pm 1 \mathrm{SE}$ of 4 values. C: control and iron addition treatments; P: phosphate and phosphate plus iron additions; $\mathrm{N}$ : nitrogen and nitrogen plus iron additions; NP: nitrogen plus phosphate and nitrogen plus phosphate plus iron additions reported as cells $\mathrm{ml}^{-1}$ and red (chl) or orange (PE) fluorescence cell- ${ }^{-1}$. Fluorescence $\mathrm{ml}^{-1}$ was derived from the product of fluorescence cell ${ }^{-1} \times$ cells $\mathrm{ml}^{-1}$ expressed in relative fluorescence units.

\section{RESULTS}

\section{General characteristics of the transect and stations}

The 8 stations sampled over the east-west transect are shown in Fig. 1a, and a nitrate contour plot is given in Fig. 1b. The depth of the nitricline decreased from east to west and reflected the presence of 2 water masses in the North Atlantic, apparent from hydroGraphic data: the castern, North Atlantic Gyre-dominated basin and the Gulf Stream-dominated western basin (Olaizola et al. 1996). Stn 1 was taken in a nearshore, upwelling area while Stn 8 was taken in relatively eutrophic water near the Grand Banks of Newfoundland, Canada. Stns 1 and 8 therefore represent endpoints of higher nitrate concentration with extensive oligotrophic areas in between. Whereas most of the transect was numerically dominated by the small prochlorophytes, Stn 1 was dominated by cyanobacteria, and prochlorophytes were absent at Stn 8. Large eukaryotic cells (retained by $1 \mu \mathrm{m}$ polycarbonate membrane) were abundant only at the last station. At all but the last station, the flow cytometer was optimized for picoplankton so that the weak fluorescence and light scatter from prochlorophyte cells could be detected. Fluorescence of large cells accumulated at the high end of the scale and could not be quantified. In the absence of prochlorophytes at Stn 8, these settings were changed to allow quantification of larger eukaryotic cells. Stn 6 exemplified the prochlorophyte-dominated, low-nitrate region of the transect, and data from this station are presented and discussed as being representative of the bulk of the transect. Complete data from all 8 stations are given in Tables 1 through 8 .

To assess the variability of pumpand-probe measurements and the possibility of diel variability in $F_{\mathrm{v}} / F_{\mathrm{m}}$ and chl a concentrations, a 201 carboy was filled and incubated in constant, dim light $\left(<50 \mu E \mathrm{~m}^{-2} \mathrm{~s}^{-1}\right)$ and 
Table 2. Chlorophyll concentration ( $\mu \mathrm{g} \mathrm{chl} \mathrm{I}^{-1}$ ), mean $\pm 1 \mathrm{SD}$ of 4 values. Treatments: control $(\mathrm{C})$; plus phosphorus $(\mathrm{P})$; plus nitrogen $(\mathrm{N})$; and plus nitrogen and phosphorus (NP). Note that the onginal 8 treatments in duplicate are here described as 4 in quadruplicate, since iron additions had no effect

\begin{tabular}{|cccccc|}
\hline \multirow{2}{*}{ Stn } & Initial & \multicolumn{4}{c|}{ Treatment } \\
& \multicolumn{7}{c}{$\mathrm{C}$} & $\mathrm{P}$ & $\mathrm{N}$ & $\mathrm{NP}$ \\
\hline 1 & - & $0.07 \pm 0.013$ & $0.05 \pm 0.006$ & $0.18 \pm 0.017$ & $0.40 \pm 0.123$ \\
2 & 0.10 & $0.07 \pm 0.008$ & $0.07 \pm 0.005$ & $0.17 \pm 0.025$ & $0.25 \pm 0.022$ \\
3 & 0.04 & $0.03 \pm 0.000$ & $0.03 \pm 0.005$ & $0.02 \pm 0.005$ & $0.02 \pm 0.005$ \\
4 & 0.07 & $0.05 \pm 0.006$ & $0.06 \pm 0.009$ & $0.09 \pm 0.008$ & $0.15 \pm 0.040$ \\
5 & 0.06 & $0.08 \pm 0.026$ & $0.06 \pm 0.023$ & $0.11 \pm 0.005$ & $0.11 \pm 0.031$ \\
6 & 0.06 & $0.07 \pm 0.022$ & $0.06 \pm 0.009$ & $0.25 \pm 0.013$ & $0.55 \pm 0.108$ \\
7 & 0.13 & $0.11 \pm 0.024$ & $0.08 \pm 0.022$ & $0.16 \pm 0.021$ & $0.20 \pm 0.022$ \\
8 & 0.59 & $0.45 \pm 0.102$ & $0.37 \pm 0.064$ & $0.63 \pm 0.046$ & $0.60 \pm 0.036$ \\
& & & & & \\
\hline
\end{tabular}

chl $a$ and $F_{v} / F_{\mathrm{m}}$ monitored over $24 \mathrm{~h}$. There was good replication of filtered subsamples at a single time point (mean $0.07 \pm 0.00 \mu \mathrm{g} \mathrm{I}^{-1}$ and $0.53 \pm 0.01$ for chlorophyll and $F_{\mathrm{v}} / F_{\mathrm{m}}$, respectively; $\mathrm{n}=5$ ) and no change over $24 \mathrm{~h}$ (mean $0.072 \pm 0.004 \mu \mathrm{gl}^{-1}$ and $0.51 \pm 0.02$ for chlorophyll and $F_{\mathrm{v}} / F_{\mathrm{m}} ; \mathrm{n}=7$ ).

Iron addition had no significant effect on any parameter measured, at any of the 8 stations $(p<0.05)$. Results from the iron addition treatments were therefore used as additional replicates for other treatments; these are $\mathrm{C}$ (= control and $+\mathrm{Fe}),+\mathrm{P}(=+\mathrm{P}$ and $+\mathrm{PFe})$, $+\mathrm{N}(=+\mathrm{N}$ and $+\mathrm{NFe})$, and $+\mathrm{NP}(=+\mathrm{NP}$ and $+N P F e$; see Table 2 ).

\section{Chlorophyll, cell abundance, and in vivo fluorescence: Stn 6}

\section{Chlorophyll and cell abundance}

Chl a concentration in control and $P$ addition treatments did not differ from the initial value (Fig. 2a, Table 2), but increased 4 -fold with $\mathrm{N}$ addition and nearly 10 -fold with addition of both $\mathrm{N}$ and $\mathrm{P}$ in this experiment. The response of cell numbers to treatment (Fig. 2b-d, Table 3) was much smaller. The numerically dominant prochlorophytes doubled in number with $\mathrm{N}$ addition and tripled with NP addition. Cyanobacterial numbers increased by about $50 \%$ over the initial value regardless of treatment, while eukaryotic cells responded positively only to a combined $N$ and $P$ addition.

\section{In vivo chlorophyll fluorescence}

Fig. 3 shows relative fluorescence due to chlorophyll (red fluorescence) per ml of sample, and the relative contributions of the 3 taxa, for Stn 6. Total fluorescence per $\mathrm{ml}$ covaried with bulk chlorophyll, giving an $r^{2}$ of 0.91 (Fig. 4). Despite their 1.5 to 2 orders of magnitude lesser abundance than prochlorophytes, the much larger eukaryotic cells contributed an equal amount to the total fluorescence signal. As with chlorophyll, fluorescence per ml did not covary with cell numbers. This is especially noticeable for cyanobacteria, whose contribution to bulk fluorescence increased by nearly 10 times with $\mathrm{N}$ addition and by 20 times with NP addition, although cell numbers changed very little and did not differ between $N$ and NP treatments (see Figs. 2c \& 3).

Table 3. Cell numbers $\left(\times 10^{2} \mathrm{ml}^{-1}\right)$ for 8 experiments; Pro: prochlorophytes; Cyan: cyanobacteria; Euk: eukaryotes $\leq 2 \mu$ m diameter. Mean \pm 1 SD of 4 values. Treatments as in Table 2

\begin{tabular}{|c|c|c|c|c|c|c|}
\hline \multirow{2}{*}{\multicolumn{2}{|c|}{$\operatorname{Stn}$}} & \multirow{2}{*}{ Initia] } & \multicolumn{4}{|c|}{ Treatment } \\
\hline & & & $\mathrm{C}$ & $\mathrm{P}$ & $N$ & NP \\
\hline \multirow{3}{*}{1} & Pro & - & $69 \pm 16$ & $52 \pm 21$ & $38 \pm 10$ & $79 \pm 40$ \\
\hline & Cyan & - & $1390 \pm 200$ & $1000 \pm 140$ & $1420 \pm 240$ & $2350 \pm 410$ \\
\hline & Euk & - & $85 \pm 9$ & $65 \pm 14$ & $23 \pm 6$ & $179 \pm 45$ \\
\hline \multirow{3}{*}{2} & Pro & 800 & $460 \pm 300$ & $570 \pm 100$ & $800 \pm 110$ & $880 \pm 120$ \\
\hline & Cyan & 74 & $79 \pm 4$ & $76 \pm 3$ & $76 \pm 3$ & $77 \pm 1$ \\
\hline & Euk & 27 & $9 \pm 0.5$ & $10 \pm 0.6$ & $12 \pm 1$ & $13 \pm 1$ \\
\hline \multirow[t]{3}{*}{3} & Pro & 130 & $480 \pm 13$ & $420 \pm 87$ & $210+56$ & $170 \pm 13$ \\
\hline & Cyan & 40 & $45 \pm 2$ & $41 \pm 3$ & $39 \pm 3$ & $36 \pm 1$ \\
\hline & Euk & 8 & $5 \pm 0.5$ & $4 \pm 0.8$ & $5 \pm 0.6$ & $4 \pm 0.5$ \\
\hline \multirow[t]{3}{*}{4} & Pro & 620 & $770 \pm 120$ & $820 \pm 190$ & $790 \pm 15$ & $720 \pm 92$ \\
\hline & Cyan & 60 & $73 \pm 2$ & $72 \pm 5$ & $67 \pm 2$ & $72 \pm 6$ \\
\hline & Euk & 10 & $6 \pm 1.5$ & $8 \pm 0.3$ & $7 \pm 1$ & $7 \pm 2$ \\
\hline \multirow[t]{3}{*}{5} & Pro & 480 & $1250 \pm 190$ & $1060 \pm 510$ & $1110 \pm 60$ & $980 \pm 260$ \\
\hline & Cyan & 25 & $39 \pm 15$ & $32 \pm 32$ & $39 \pm 3$ & $31 \pm 9$ \\
\hline & Euk & 15 & $14 \pm 0.7$ & $11 \pm 5$ & $14 \pm 0.4$ & $12 \pm 4$ \\
\hline \multirow[t]{3}{*}{6} & Pro & 440 & $580 \pm 100$ & $540 \pm 35$ & $910 \pm 19$ & $1290 \pm 31$ \\
\hline & Cyan & 53 & $80 \pm 5$ & $78 \pm 10$ & $83 \pm 5$ & $91 \pm 5$ \\
\hline & Euk & 10 & $8 \pm 0.4$ & $7 \pm 1$ & $10 \pm 1$ & $14 \pm 1$ \\
\hline \multirow[t]{3}{*}{7} & Pro & 110 & $170 \pm 12$ & $180 \pm 18$ & $150 \pm 3$ & $160 \pm 4$ \\
\hline & Cyan & 290 & $350 \pm 5$ & $330 \pm 12$ & $320 \pm 12$ & $340 \pm 9$ \\
\hline & Euk & 30 & $25 \pm 1$ & $25 \pm 1$ & $26 \pm 2$ & $28 \pm 0.7$ \\
\hline \multirow{3}{*}{8} & Cyan & 270 & $370 \pm 12$ & $370 \pm 6$ & $360 \pm 14$ & $350 \pm 20$ \\
\hline & Euk & 85 & $96 \pm 5$ & $96 \pm 6$ & $110 \pm 4$ & $120 \pm 7$ \\
\hline & Euk $(>2 \mu m)$ & 20 & $22 \pm 1$ & $20 \pm 1$ & $21 \pm 1$ & $22 \pm 1$ \\
\hline
\end{tabular}




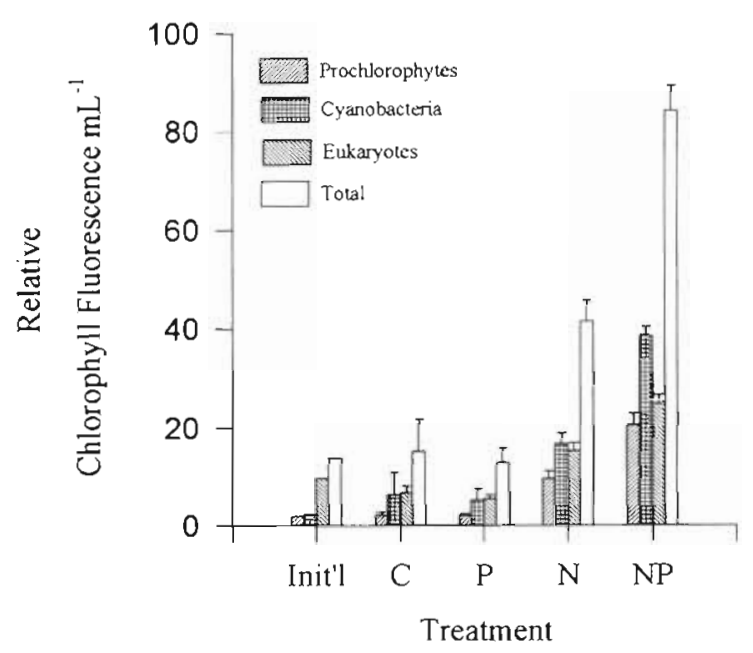

Fig. 3. Relative red (chlorophyll) fluorescence per ml due to prochlorophytes, cyanobacteria, eukaryotes, and in total, Stn 6.

Fluorescence is in arbitrary units. Treatments as in Fig. 2

\section{Fluorescence per cell}

Since total chlorophyll concentration varied independently of cell numbers, the chlorophyll content of cells must necessarily have changed. In fact the variation in fluorescence per cyanobacterial cell, numbers of which changed very little, could be used to explain most of the variation $\left(r^{2}=0.995\right.$, slope $\left.=0.96\right)$ in bulk chlorophyll concentration at Stn 6 (Fig. 5a, d). Cellular red fluorescence of cyanobacteria responded much more dramatically to $N$ additions than did fluorescence of prochlorophytes or eukaryotes (Fig 5b, c).

The eukaryotic phytoplankton were characterized by cellular chlorophyll fluorescence values 100 to 200 times greater than those measured in prochlorophytes (Table 4, Fig. 5b, c). Therefore, despite their low abundance these picoplankton were an important component of the red fluorescence signal and by inference of the chlorophyll standing stock. The smaller magnitude of cellular fluorescence response in the eukaryotes than in either prokaryotic taxon may reflect a longer generation time of these cells, or more rapid response of the prokaryotes to increased nutrient availability.

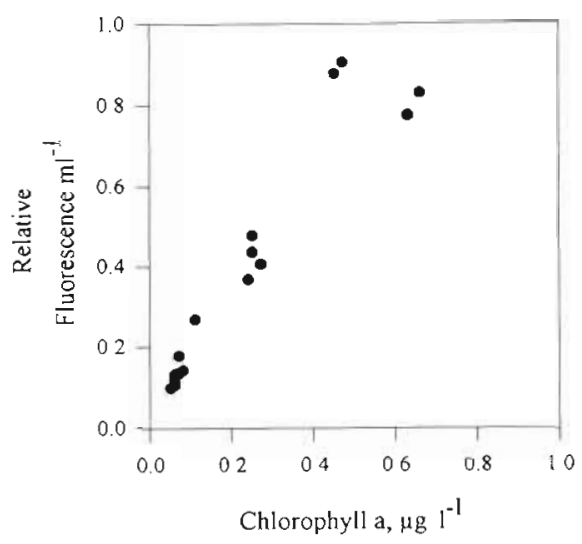

Fig. 4. Total relative chlorophyll fluorescence per $\mathrm{ml}$ versus chlorophyll concentration for the initial sample and final samples from 16 bottlos, Stn 6 . Fluorescence is in arhitrary units.

Linear regression analysis gives $\mathrm{r}^{2}=0.91$

Overall, as exemplified for Stn 6, the cyanobacteria exhibited the greatest physiological response to $\mathrm{N}$ addition by accumulation of photosynthetic pigments (Tables 4 \& 5), but were unable to increase in numbers. The prochlorophytes were also able to increase their pigment content when $\mathrm{N}$ was added, although to a lesser extent. These cells were also able to increase in
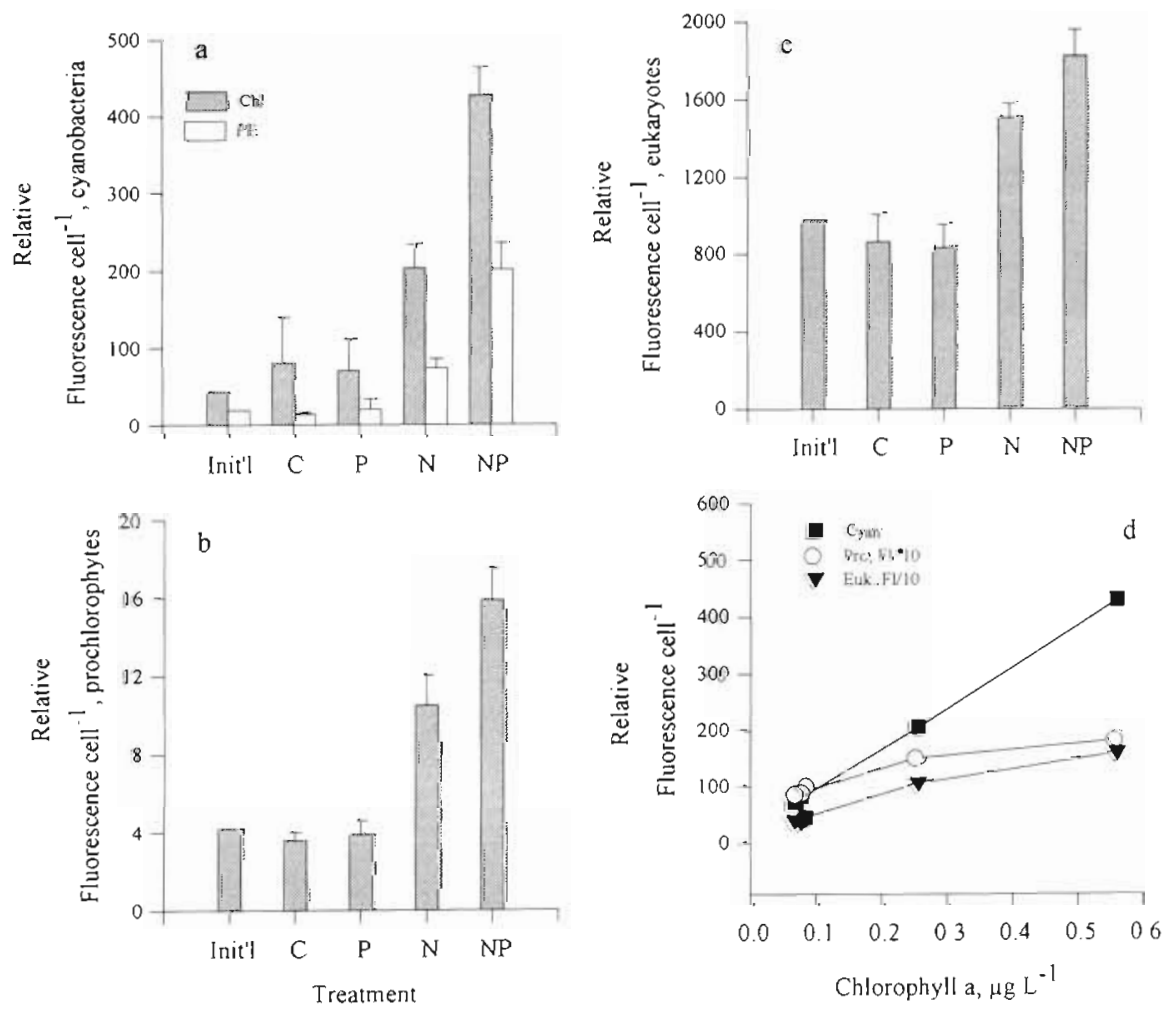

Fig. 5. Relative red (chlorophyll) and orange (phycoerythrin, PE) fluorescence per cell for (a) cyanobacteria, (b) prochlorophytes, and (c) eukaryotes, Stn 6 . Treatments as in Fig. 2. (d) Chlorophyll fluorescence per cell for the same 3 groups, plotted against chl a. Fluorescence in arbitrary units 
Table 4. Chl a (red, $\lambda>630 \mathrm{~nm})$ fluorescence $\mathrm{cell}^{-1}$ in relative fluorescence units for prochlorophytes, cyanobacteria, and eukaryotes. Mean \pm 1 SD of 4 values. Treatments as in Table 2

\begin{tabular}{|c|c|c|c|c|c|c|}
\hline \multirow{2}{*}{\multicolumn{2}{|c|}{ Stn }} & \multirow[t]{2}{*}{ Initial } & \multicolumn{4}{|c|}{ Treatment } \\
\hline & & & $\mathrm{C}$ & $\mathrm{P}$ & $N$ & NP \\
\hline \multirow[t]{3}{*}{1} & Pro & - & $6 \pm 0.8$ & $6 \pm 0.8$ & $13 \pm 0.5$ & $13 \pm 0.6$ \\
\hline & Cyan & - & $33 \pm 15$ & $30 \pm 13$ & $170 \pm 10$ & $220 \pm 21$ \\
\hline & Euk & - & $276 \pm 14$ & $256 \pm 15$ & $827 \pm 110$ & $489 \pm 20$ \\
\hline \multirow[t]{3}{*}{2} & Pro & 4 & $3 \pm 0.05$ & $3 \pm 0.3$ & $4 \pm 0.3$ & $4 \pm 0.2$ \\
\hline & Cyan & 25 & $50 \pm 21$ & $45 \pm 2$ & $125 \pm 20$ & $158 \pm 21$ \\
\hline & Euk & 696 & $490 \pm 44$ & $517 \pm 28$ & $883 \pm 49$ & $943 \pm 97$ \\
\hline \multirow[t]{3}{*}{3} & Pro & 4 & $6 \pm 0.3$ & $5 \pm 0.3$ & $4 \pm 0.1$ & $4 \pm 0.1$ \\
\hline & Cyan & 22 & $118 \pm 19$ & $120 \pm 10$ & $114 \pm 8$ & $115 \pm 5$ \\
\hline & Euk & 1075 & $633 \pm 57$ & $622 \pm 50$ & $510 \pm 71$ & $512 \pm 81$ \\
\hline \multirow[t]{3}{*}{4} & Pro & 4 & $4 \pm 0.4$ & $4 \pm 0.3$ & $6 \pm 0.1$ & $7 \pm 0.3$ \\
\hline & Cyan & 30 & $96 \pm 40$ & $133 \pm 96$ & $221 \pm 78$ & $344 \pm 17$ \\
\hline & Euk & 1110 & $710 \pm 99$ & $861 \pm 114$ & $836 \pm 65$ & $1134 \pm 186$ \\
\hline \multirow[t]{3}{*}{5} & Pro & 5 & $7 \pm 4$ & $8 \pm 3$ & $12 \pm 0.6$ & $14 \pm 0.3$ \\
\hline & Cyan & 39 & $153 \pm 74$ & $184 \pm 58$ & $317 \pm 13$ & $392 \pm 14$ \\
\hline & Euk & 974 & $1230 \pm 129$ & $1270 \pm 161$ & $1420 \pm 69$ & $1620 \pm 106$ \\
\hline \multirow[t]{3}{*}{6} & Pro & 4 & $4 \pm 0.4$ & $4 \pm 0.7$ & $11 \pm 2$ & $16 \pm 2$ \\
\hline & Cyan & 43 & $80 \pm 60$ & $70 \pm 41$ & $203 \pm 31$ & $427 \pm 37$ \\
\hline & Euk & 974 & $864 \pm 142$ & $835 \pm 119$ & $1500 \pm 72$ & $1820 \pm 135$ \\
\hline \multirow[t]{3}{*}{7} & Pro & 6 & $6 \pm 0.3$ & $6 \pm 0.7$ & $9 \pm 0.3$ & $11 \pm 0.5$ \\
\hline & Cyan & 37 & $51 \pm 18$ & $52 \pm 6$ & $82 \pm 4$ & $137 \pm 4$ \\
\hline & Euk & 701 & $577 \pm 86$ & $498 \pm 37$ & $752 \pm 66$ & $951 \pm 41$ \\
\hline \multirow[t]{3}{*}{8} & Cyan & 32 & $30 \pm 2$ & $32 \pm 6$ & $49 \pm 2$ & $46 \pm 1$ \\
\hline & Euk & 284 & $284 \pm 11$ & $272 \pm 29$ & $364 \pm 18$ & $355 \pm 10$ \\
\hline & Euk $(>2 \mu \mathrm{m})$ & 6640 & $5020 \pm 82$ & $4740 \pm 624$ & $6180 \pm 520$ & $5970 \pm 293$ \\
\hline
\end{tabular}

\section{DISCUSSION}

\section{Measurement of red fluorescence as a substitute for chl a}

Phytoplankton populations throughout the bulk of the transect were numerically dominated by prochlorophytes, with cyanobacteria being less abundant and relatively low numbers of the mixed pico-eukaryote assemblage present. In our use of red fluorescence signals as an analog for chlorophyll, we have assumed that summed total red fluorescence included most of the phytoplankton present, and that larger cells were not major contributors to bulk chlorophyll. This assumption is supported by the regression analyses of summed red fluorescence on bulk chlorophyll (Table 7 ), with $r^{2}$ values ranging from 0.59 to 0.97 , although in one case (Stn 3, $r^{2}=0.41$ ) the slope was not significantly different from zero. Veldhuis et al. (1996) noted a similar linear relationship between flow cytometer fluorescence measurements and total chlorophyll in Indian Ocean picoplankton communities. Along this North Atlantic transect, side scatter versus red fluorescence plots (4 decade scale) showed nearly identical results before and after filtration abundance by as much as 3 -fold. The small eukaryotic cells showed a mixed response but appeared less able than the prokaryotes to take advantage of nutrient additions.

\section{Photochemical efficiency}

The ratio of variable to maximum fluorescence $\left(F_{\mathrm{v}} / F_{\mathrm{m}}\right)$ varied little throughout most of the transect and with nutrient additions (Table 6). Initial values ranged from 0.42 to 0.45 , except at Stn 8 where the lowest value, 0.27 , was observed. Values for each treatment from Stns 6 and 8 are shown in Fig. 6. In most experiments an increase over initial values occurred in all bottles regardless of treatment, while slightly higher values were measured in plus $\mathrm{N}$ treatments. These differences were not significant at $p<0.05$, however. The exception to this was $\operatorname{Stn} 8$, where $N$ addition resulted in significantly higher values than those measured either initially or in the control treatment. through a $2 \mu \mathrm{m}$ PC membrane (Li 1994), with only the rare cells of greater than 200 units side scatter being retained on the filter. In addition, summed ${ }^{14} \mathrm{C}$ uptake per $\mathrm{ml}$ from sorted samples accounted for $>90 \%$ of the total ${ }^{14} \mathrm{C}$ uptake in unsorted samples ( $\mathrm{Li}$ 1994), although it

Table 5. Phycoerythrin (orange, $\lambda=564$ to $606 \mathrm{~nm}$ ) fluorescence cell ${ }^{-1}$ in relative fluorescence units for cyanobacteria. Mean \pm 1 SD of 2 replicates. Treatments as in Table 2

\begin{tabular}{|c|c|c|c|c|c|}
\hline \multirow[t]{2}{*}{ Stn } & \multirow[t]{2}{*}{ Initial } & \multicolumn{4}{|c|}{ Treatment } \\
\hline & & $\mathrm{C}$ & $\mathrm{P}$ & $N$ & NP \\
\hline 1 & - & $45 \pm 24$ & $44 \pm 24$ & $274 \pm 32$ & $312 \pm 42$ \\
\hline 2 & 12 & $28 \pm 18$ & $16 \pm 3$ & $51 \pm 6$ & $59 \pm 9$ \\
\hline 3 & 7 & $44 \pm 8$ & $34 \pm 8$ & $42 \pm 5$ & $34 \pm 2$ \\
\hline 4 & 14 & $49 \pm 27$ & $62 \pm 63$ & $115 \pm 4$ & $171 \pm 14$ \\
\hline 5 & 18 & $11 \pm 42$ & $79 \pm 35$ & $148 \pm 13$ & $193 \pm 18$ \\
\hline 6 & 19 & $29 \pm 29$ & $20 \pm 16$ & $73 \pm 14$ & $203 \pm 37$ \\
\hline 7 & 9 & $11 \pm 5$ & $9 \pm 2$ & $18 \pm 2$ & $32 \pm 4$ \\
\hline 8 & 24 & $24 \pm 2$ & $24 \pm 4$ & $38 \pm 2$ & $36 \pm 1$ \\
\hline
\end{tabular}


Table 6. $F_{\mathrm{v}} / F_{\mathrm{m}}$ (ratio of variable fluorescence to maximum fluorescence yield). Mean \pm 1 SD of 4 values. Treatments as in Table 2

\begin{tabular}{|cccccc|}
\hline Stn & Initial & \multicolumn{4}{c|}{ Treatment } \\
& & $\mathrm{C}$ & $\mathrm{P}$ & $\mathrm{N}$ & $\mathrm{NP}$ \\
\hline 1 & - & $0.43 \pm 0.04$ & $0.39 \pm 0.02$ & $0.48 \pm 0.01$ & $0.48 \pm 0.04$ \\
2 & $0.48 \pm 0.03$ & $0.44 \pm 0.03$ & $0.36 \pm 0.04$ & $0.35 \pm 0.09$ & $0.45 \pm 0.04$ \\
3 & $0.44 \pm 0.03$ & $0.49 \pm 0.02$ & $0.52 \pm 0.02$ & $0.43 \pm 0.04$ & $0.45 \pm 0.03$ \\
4 & $0.47 \pm 0.01$ & $0.47 \pm 0.02$ & $0.49 \pm 0.01$ & $0.50 \pm 0.02$ & $0.50 \pm 0.02$ \\
5 & $0.44 \pm 0.02$ & $0.51 \pm 0.02$ & $0.51 \pm 0.03$ & $0.51 \pm 0.02$ & $0.52 \pm 0.03$ \\
6 & $0.42 \pm 0.01$ & $0.44 \pm 0.04$ & $0.45 \pm 0.02$ & $0.51 \pm 0.03$ & $0.50 \pm 0.03$ \\
7 & $0.44 \pm 0.01$ & $0.46 \pm 0.03$ & $0.46 \pm 0.02$ & $0.48 \pm 0.02$ & $0.48 \pm 0.03$ \\
8 & $0.27 \pm 0.02$ & $0.32 \pm 0.03$ & $0.34 \pm 0.06$ & $0.45 \pm 0.04$ & $0.44 \pm 0.03$ \\
\hline
\end{tabular}

is attributable to phycoerythrin. The overlap in emission peaks of these pigments is small (see for example Yentsch \& Phinney 1990, Fig. 5), so the percent contribution of PE fluorescence to total fluorescence above $650 \mathrm{~nm}$ depends on the relative magnitude of the 2 peaks, which is very difficult to determine by flow cytometry. Based on fluorescence emission spectra from several PE-containing species (Yentsch \& Phinney 1990, D. A. Phinney \& T. Cucci unpubl.), it is estimated that between 5 and $25 \%$ of fluorescence over $650 \mathrm{~nm}$ may be was pointed out that largo, rare cells may be under-represented in small volume samples. At Stn $8\left(r^{2}=0.59\right)$ chlorophyll fluorescence was almost certainly underestimated, due to the presence of larger cells. With the exception of Stn 8, red fluorescence measurements of sorted samples therefore accounted for most of the chlorophyll present in our experiments.

Changes in cyanobacterial red fluorescence were highly correlated with changes in orange (PE) fluorescence. This may be due in part to tailing of the phycoerythrin fluorescence peak into the red region, which is not compensated for such spillover, such that part of the red fluorescence signal displayed by cyanobacteria
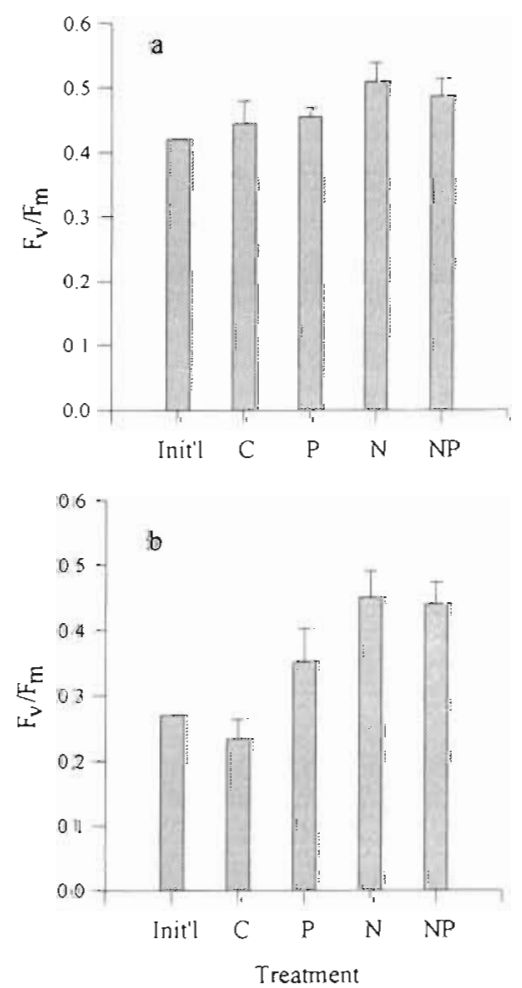

Fig. 6. $F_{\mathrm{v}} / F_{\mathrm{m}}$ for (a) $\operatorname{Stn} 6$ and (b) $\operatorname{Stn} 8$. Treatments as in Fig. 2 attributed to PF. with stationary phase DC2 having the lowest relative chlorophyll fluorescence. Kana et al. (1992) noted that fluorescence emission spectra of 3 strains of Synechococcus sp. in log phase showed distinct $P E$ and chlorophyll peaks of about equal magnitude. The contribution of PE to red fluorescence in that case would be small (less than $5 \%$ ). Red fluorescence values in the present study are therefore contaminated by PE fluorescence to an unknown extent, but within the bounds estimated above. It is probable that for mixed oceanic populations, the contribution of $\mathrm{PE}$ to the red fluorescence measured is at the low end of the range, closer to 10 than to $25 \%$.

\section{Physiological and ecological components of pigment increase}

Observed changes in cellular red fluorescence and cell abundance can be used to infer the nutrient status of the prochlorophytes, cyanobacteria, and eukaryotic picoplankton. Since cellular fluorescence provides a relative rather than absolute index of nutrient status, initial observations revealing the in situ conditions were compared with observations on control and nutrient amended samples. In 6 of the 8 experiments discussed here, total cellular fluorescence $(F l)$ covaried significantly with chlorophyll (Table 7), while cell numbers did not. Therefore changes in fluorescence may be interpreted as indicative of changes in cellular chlorophyll content. In general, then, chlorophyll concentration changed in response to physiological effects of treatment rather than with changing cell abundance. This was especially true for cyanobacteria which showed the largest response to incubation with added nitrogen, while cell numbers changed relatively little.

Phycoerythrin (PE), here measured as an 'orange' fluorescence signal and covarying with chlorophyll fluorescence, is the major light-harvesting pigment of 
Table 7. Comparison of $F_{0}$, Fl (total cellular fluorescence), and chl a concentration by Model 1 linear regression analysis

\begin{tabular}{|c|c|c|c|}
\hline Stn & $\begin{array}{c}F l \vee{ }^{2} F_{0} \\
\mathrm{r}^{2}\end{array}$ & $\begin{array}{c}\text { Fl vs chl } a \\
\mathrm{r}^{2}\end{array}$ & $\begin{array}{c}F_{01} \text { vs chl } d \\
\mathrm{r}^{2}\end{array}$ \\
\hline 1 & 0.88 & 0.97 & 0.94 \\
\hline 2 & 0.78 & 0.71 & 0.72 \\
\hline 3 & $0.05^{\circ}$ & $0.41^{\circ}$ & 0.68 \\
\hline 4 & $0.26^{\circ}$ & 0.79 & $0.44^{\circ}$ \\
\hline 5 & 0.77 & 0.96 & 0.85 \\
\hline 6 & 0.93 & 0.91 & 0.86 \\
\hline 7 & 0.74 & 0.82 & 0.73 \\
\hline 8 & $0.01^{\circ}$ & 0.59 & $0.002^{\circ}$ \\
\hline
\end{tabular}

cyanobacteria. Repressed synthesis and/or active degradation of cyanobacterial phycobilisomes under nitrogen starvation has been described by many authors (e.g. Collier \& Grossman 1992). In the present study cellular PE fluorescence responded to $\mathrm{N}$ addition at all but Stn 3, as did chlorophyll fluorescence. In several experiments both PE and chlorophyll fluorescence increased in control treatments (Tables 4 \& 5), and we suspect this may have been a response to low light. At most stations, the irradiance used for on-deck incubations was lower than at the depth from which samples were taken, perhaps leading to active pigment synthesis as a consequence of photoadaptation to low light. The greater ability of cells, when supplied with additional $\mathrm{N}$, to compensate for decreased irradiance by increasing pigment content would further indicate in situ nitrogen limitation. It should be noted, however, that the change in PE fluorescence (initial to final values, all treatments) did not covary with change in irradiance (from collection to incubation depth)

\section{Nutrient limitation and fluorescence parameters}

$F_{\mathrm{v}} / F_{\mathrm{m}}$ is calculated from 2 measurements: the minimum fluorescence $\left(F_{0}\right)$ from dark-adapted cells with all functional reaction centers 'open' ( $Q_{a}$ is oxidized), and the maximum fluorescence $\left(F_{\mathrm{m}}\right)$ after all reaction centers have been closed by a saturating flash of light (Kolber et al. 1988). The difference between these $\left(F_{\mathrm{m}}-F_{0}=F_{\mathrm{v}}\right)$, normalized to $F_{\mathrm{m}}$, is a measure of photochemical efficiency. $F_{0}$ and $F_{\mathrm{m}}$ normalized to chlorophyll also give physiological information; patterns of $F_{0}$ and $F_{\mathrm{m}} / \mathrm{chl} \mathrm{a}^{-1}$ across the transect and with depth are discussed in detail by Olaizola et al. (1996).

Cellular fluorescence emission, designated $f_{\text {, }}$ can be divided into 2 components: fluorescence efficiency $\left(\varnothing_{f}\right.$ dimensionless), and a light absorption coefficient ( $a_{\mathrm{cel}}$. with units of $\mathrm{m}^{2}$ cell-1). The coefficient $a_{\text {cell }}$ can be fur- ther divided into cell chlorophyll content (pg chl a cell ${ }^{-1}$ ) and a chlorophyll-specific light absorption coefficient, $a_{\mathrm{chl}}\left(\mathrm{m}^{2} \mathrm{pg} \mathrm{chl} \mathrm{a}^{-1}\right)$, giving:

$$
f=\sigma_{l}\left(\text { chl cell }{ }^{-1}\right)\left(\alpha_{\text {chl }}\right)
$$

All of the parameters on the right hand side of this equation have been observed to change with nutrient limitation, complicating interpretation of cell fluorescence. Several studies have demonstrated that $a_{c h l}$ increases under nitrogen limitation although cell chlorophyll and accessory pigment content declines (Osborne \& Geider 1986, Kolber et al. 1988, Herzig \& Falkowski 1989). This results from an increase in accessory pigment:chlorophyll ratio and therefore an increase in light-harvesting antennae size relative to PSII reaction center chlorophyll (Herzig \& Falkowski 1989), as well as from a decrease in the package effect (Geider et al. 1993b).

Effects of nutrient limitation on fluorescence efficiency are more complex. As the amount of PSII antennae pigment declines, total fluorescence emission also declines. However, $N$ limitation also causes a loss of proteins required for photochemical energy conversion, and a resultant increase in fluorescence from the photochemically inactive reaction centers (Kolber et al. 1988). Effects of nutrient limitation which may be seen as an increase in $F_{0}$ therefore include a loss of functional PSII reaction centers and/or inefficient energy transfer to reaction centers, due to loss of key proteins (Kolber et al. 1988, Falkowski et al. 1989); increased chlorophyll-specific absorbance due to decreased cell chlorophyll content (Berner et al. 1989); and changes in the accessory pigment:chlorophyll ratio (Sosik \& Mitchell 1991). $F_{n i}$ will respond primarily to changes in chlorophyll-specific absorption and relative pigment content. At Stn $8, F_{0} / \mathrm{chl} a^{-1}$ was significantly lower in $\mathrm{N}$-amended treatments while $F_{\mathrm{m}} / \mathrm{chl} \mathrm{a}^{-1}$ was not ( $\mathrm{p}=$ $0.05)$. This reduction is consistent with a decrease of $\Phi_{F_{0}}$ and implies repair of damaged PSII reaction centers following $N$ addition. At all other stations, $F_{0} / \mathrm{chl}$ $a^{-1}$ varied more closely with $F_{\mathrm{m}} / \mathrm{chl} a^{-1}$, indicating little or no change in fluorescence efficiency with treatment, as expressed in the $F_{\mathrm{v}} / F_{\mathrm{m}}$ values.

\section{Application of $F_{\mathrm{v}} / F_{\mathrm{m}}$ as a diagnostic of nutrient limitation}

The parameter $F_{\mathrm{v}} / F_{\mathrm{m}}$ is physiologically constrained to a narrow range independent of taxon, with a maximum value of about 0.64 in nutrient replete cultures, and a minimum of about 0.3 in N-limited cultures growing at $10 \%$ of their nutrient saturated rate (Kolber et al. 1988). Thus the absolute value of $F_{\mathrm{v}} / F_{\mathrm{m}}$ is an absolute measure of the maximum efficiency of photo- 
system II photochemistry, and is proportional to the maximum quantum efficiency of photosynthesis, $\Phi_{m}$ (Geider 1993). This biophysical index is fundamentally different from physiological indices such as chl a cell-t, which vary with taxon as well as physiological state of the cell. Since variable fluorescence is virtually independent of growth temperature and irradiance under nutrient sufficiency, it is an excellent, and relatively non-intrusive, biophysical approach to examining nutrient limitation of phytoplankton photosynthesis (Geider 1993). Low values of $F_{\mathrm{v}} / F_{\mathrm{m}}$ have been consistently correlated with reduced growth rates in nitrogen-, iron-, and phosphorus-limited cultures (Kolber et al. 1988, Greene et al. 1992, Geider et al. 1993b, Graziano et al. 1996) and low photosynthesis rates in

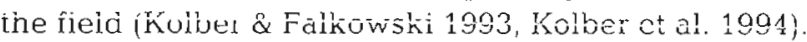
$F_{\mathrm{v}} / F_{\mathrm{m}}$ is a non-linear function of growth rate and does not decline significantly until the relative growth rate falls below $50 \%$ of $\mu_{\max }$ (Kolber et al. 1988, Graziano et al. 1996). Measurements made during the same transect as a basin-wide study of variations in $\Phi_{\mathrm{m}}$, and a more in-depth discussion of the use of $F_{\mathrm{v}} / F_{\mathrm{m}}$ in field studies of nutrient limited photosynthesis and growth, are presented in Olaizola et al. (1996). Our observations of low values of $F_{\mathrm{y}} / F_{\mathrm{m}}$ are consistent with nutrient limitation of photochemical energy conversion and therefore of growth rates of North Atlantic picoplankton.

At Stns 1 through 7 in this study, water was taken from below the surface but above the chlorophyll maximum (20 to $65 \mathrm{~m}$ ). Addition of nitrogen did not significantly $(\mathrm{p}<0.05)$ increase $F_{\mathrm{v}} / F_{\mathrm{m}}$ at any of these stations although enclosure did, while the highest value measured after incubation (0.52) was still lower than that found in coastal, nutrient-rich waters. Water column values were low compared with the physiological maximum of 0.64 . Assuming a strict proportionality between $F_{\mathrm{v}} / F_{\mathrm{m}}$ and fraction of functional reaction centers, and that all reaction centers are functional when $F_{v} / F_{m}=0.64$ (Greene et al. 1994), between 25 and $35 \%$ of PSII reaction centers were non-functional over our transect. Other investigators have observed low $F_{\mathrm{v}} / F_{\mathrm{m}}$ values in the ocean, including the equatorial Pacific (Greene et al. 1994, Kolber et al. 1994), the Sargasso Sea (Geider et al. 1993a) and the Gulf of Maine (Kolber et al. 1990). It is significant that incubations with nutrient additions fail to result in full recovery (Greene et al. 1994), even over 5 to $6 \mathrm{~d}$ incubations. The exception to this finding is the in situ iron fertilization experiment carried out in the equatorial Pacific (Kolber et al. 1994), where values of $F_{\mathrm{v}} / F_{\mathrm{m}}$ increased from about 0.3 to over 0.6 within $2 \mathrm{~d}$ of water column iron enrichment.

It seems that some factor in addition to nitrogen availability in the North Atlantic causes the depressed
$F_{\mathrm{v}} / F_{\mathrm{m}}$, and that this was partially alleviated by enclosure in bottles. Values tended to increase with $\mathrm{N}$ addition, although only at $\operatorname{Stn} 8$ was this increase significant at $\mathrm{p}<0.05$. Other factors which may dffect this measurement are discussed by Geider et al. (1993b). Confounding effects of xanthophyll cycling are eliminated by a 30 min dark-adaptation time prior to fluorescence measurements and by low incubation irradiance, so non-photochemical quenching should not have caused a reduction in $F_{\mathrm{v}} / F_{\mathrm{m}}$. It is possible that the presence of cyanobacteria may reduce $F_{\mathrm{v}} / F_{\mathrm{m}}$, due to their relatively high zeaxanthin:chlorophyll ratios which may result in non-photochemical fluorescence quenching ( $\mathrm{J}$. La Roche unpubl. data). However, the numerical dominance of cyanobacteria at our Stns 1, 7, and 8 did not rorrespond to low initial variable fluorescence or to the magnitude of increase in our incubations.

Despite the failure of $\mathrm{N}$-amended samples to recover in terms of photochemical efficiency, $N$ addition clearly resulted in increased pigmentation. It is possible that the time-course of incubation allowed an increase in pigment synthesis under $\mathrm{N}$ sufficiency, but was too short to allow repair of protein components of the photosynthetic apparatus. This differs from previous findings (Geider et al. 1993b, Kolber et al. 1994) that an increase in both $F_{\mathrm{v}} / F_{\mathrm{m}}$ and chl a cell ${ }^{-1}$ occurs within $24 \mathrm{~h}$ of nutrient addition.

The last experiment (Stn 8) was conducted with near-surface water where the algae were severely nutrient stressed in situ as judged by the low value of $F_{\mathrm{v}} / F_{\mathrm{m}}(0.27)$. A much greater response of variable fluorescence to nitrogen addition was observed at this station than at any other. Despite the presence of many larger cells, however, $F_{v} / F_{m}$ was only 0.45 in $\mathrm{N}$ enriched samples, lower than the maximum reached in all but the most oligotrophic station. The $24 \mathrm{~h}$ incubation time used may have been insufficient to allow full physiological recovery of this assemblage. However, partial recovery of $F_{\mathrm{v}} / F_{\mathrm{m}}$ provides strong evidence for physiological limitation by nitrogen in situ at Stn 8.

\section{CONCLUSIONS}

The principal experimental tool used to determine the nutrient(s) limiting phytoplankton productivity has been the nutrient addition bioassay. Such experiments have provided evidence for nitrogen limitation of phytoplankton abundance in subtropical gyres and coastal areas (Fisher et al. 1992, DiTullio et al. 1993). However, interpretation of results is controversial due to artifacts associated with confining a natural assemblage in bottles for a day or longer. We employed pump-and-probe measurements of photochemical effi- 
ciency $\left(F_{\mathrm{v}} / F_{\mathrm{n}}\right)$ and flow cytometric measurements of abundance and cellular fluorescence, in order to examine physiological responses independently of cell abundance in nutrient addition experiments. Observations have been interpreted within the context of documented variability in chlorophyll content and photosynthetic efficiency of phytoplankton under nutrient limited conditions (Kolber et al. 1988, Geider 1993).

Overall, these experiments suggest in situ nitrogen limitation of cell biomass (numbers and/or pigment content) and photosynthetic physiology of the 3 taxa investigated. The results are summarized in Table 8 . In several cases the prokaryotes appeared to outcompete the eukaryotes for added nutrients, as indicated by a decline in number and cell fluorescence of eukaryotes. In other instances, eukaryotic cell chlorophyll was enhanced by $\mathrm{N}$ addition but numbers declined, either because of increased grazing or decreased division rate. Cyanobacterial numbers did not respond to treatment, although cellular fluorescence increased over initial values in all experiments, indicating increased pigment content and possibly faster division rates. The most oligotrophic station (Stn 3) was exceptional in that some factor other than nutrient availability appeared to constrain algal biomass and cellular chlorophyll.

Pump-and-probe fluorescence measurements indicated low photosynthetic efficiency across the entire transect. It is interesting that within a 1 or $2 \mathrm{~d}$ incubation, photochemical efficiency was significantly improved only at the relatively eutrophic station, where an extremely low initial value was measured. Large increases in cellular pigment content, and lesser increases in cell numbers with nitrogen addition, strongly imply both physiological and biomass limitation by nitrogen.

Table 8. Summary of results of nitrogen addition in 8 experiments. $+\mathrm{N}$ treatments include $\mathrm{N}, \mathrm{NFe}, \mathrm{NP}$, and All. Response is indicated by,+- , or 0 relative to control. "Indicates a decrease from initial value. np: not present

\begin{tabular}{|c|c|c|c|c|c|c|c|c|}
\hline \multirow{2}{*}{ Stn } & \multirow{2}{*}{$\begin{array}{c}\text { Chl } \\
\left(\mu \mathrm{g} \mathrm{l}^{-1}\right)\end{array}$} & \multirow{2}{*}{$F_{\mathrm{v}} / F_{\mathrm{m}}^{\mathrm{d}}$} & \multicolumn{3}{|c|}{ Cell red Fl } & \multicolumn{3}{|c|}{ Cells $\mathrm{ml}^{-1}$} \\
\hline & & & Pro & Cyan & Euk & Pro & Cyan & Euk \\
\hline 1 & + & + & + & + & ++ & - & 0 & 0 \\
\hline 2 & + & 0 & $+^{\circ}$ & + & + & + & 0 & $+^{\circ}$ \\
\hline 3 & $-\cdot$ & - & - & 0 & $-\cdot$ & - & - & $0^{\circ}$ \\
\hline 4 & + & + & + & + & + & 0 & 0 & $0^{\circ}$ \\
\hline 5 & + & 0 & + & + & + & - & 0 & 0 \\
\hline 6 & ++ & + & + & + & + & + & 0 & + \\
\hline 7 & + & + & + & + & + & 0 & 0 & $0^{\circ}$ \\
\hline 8 & + & + & $n p$ & + & + & $n p$ & 0 & + \\
\hline
\end{tabular}

Acknowledgements. The authors thank Glen Harrison (chief scientist) and Brian Irwin for advice and assistance during the cruise, Zbigniew Kolber and Paul Falkowski for use of the pump-and-probe fluorometer, George Luther for advice and assistance with cruise preparation, Phil Yates for loan of the clean bench, and the officers and crew of the CSS 'Hudson' for smooth sailing. Nutrient analyses were provided by Brian Irwin. This research was funded by NSF grant number OCE9300491 and Delaware Sea Grant number RB/34 to R.J.G., and the following Canadian Government Organizations: Department of Fisheries and Oceans, Department of National Defense, Canadian Panel of Energy R \& D, and the interdepartmental 'Green Plan' Support was also provided by the Jount Research Centre, Commission of the European Communitıes. M.O. was supported by a European Commission Postdoctoral Fellowship

\section{LITERATURE CITED}

Berner T, Dubinsky A, Wyman K, Falkowski PG (1989) Photoadaptation and the 'package' effect in Dunaliella tertiolecta. J Phycol 25:70-78

Collier JL, Grossman AR (1992) Chlorosis induced by nutrient deprivation in Synechococcus sp. strain PCC 7942: not all bleaching is the same. J Bacteriol 174:4718-4726

Cullen J, Yang X, Macintyre HL (1992) Nutrient limitation and marine photosynthesis. In: Falkowski PG, Woodhead $\mathrm{AD}$ (eds) Primary productivity and biogeochemical cycles in the sea. Plenum, New York, p 69-88

DiTullio GR, Hutchins DA, Bruland KW (1993) Interaction of iron and major nutrients controls phytoplankton growth and species composition in the tropical North Pacific Ocean. Limnol Oceanogr 38:495-508

Dugdale RC, Goering JJ (1967) Uptake of new and regenerated forms of nitrogen in primary productivity. Limnol Oceanogr 12:196-206

Dugdale RC, Wilkerson F (1992) Nutrient limitation of new production in the sea. In: Falkowski PG, Woodhead AD (eds) Primary productivity and biogeochemical cycles in the sea. Plenum, New York, p 107-122

Falkowski PG, Greene RM, Geider RJ (1992) Physiological limitations on phytoplankton productivity in the ocean. Oceanography 5:84-91

Falkowski PG, Sukenik A, Herzig R (1989) Nitrogen limitation in Isochrysis galbana (Haptophyceae). II. Relative abundance of chloroplast proteins. J Phycol 25 $471-478$

Fisher TR, Peele ER, Ammerman JW, Harding LW (1992) Nutrient limitation of phytoplankton in Chesapeake Bay. Mar Ecol Prog Ser 82:51-63

Geider RJ (1993) Quantitative phytoplankton physiology: implications for primary production and phytoplankton growth. ICES Mar Sci Symp 197:52-62

Geider RJ, Greene RM, Kolber Z, MacIntyre H, Falkowski PG (1993a) Fluorescence assessment of the maximum quantum efficiency of photosynthesis in the western North Atlantic. Deep Sea Res 40:1205-1224

Geider RJ, LaRoche J, Greene RM, Olaizola M (1993b) Response of the photosynthetic apparatus of Phaeodactylum tricornutum (Bacillariophyceae) to nitrate, phosphate, or iron starvation. J Phycol 29:755-766

Goldman JC (1980) Physiological processes, nutrient availability and the concept of relative growth rate in marine phytoplankton ecology. In: Falkowski PG, Woodhead AD (eds) Primary productivity and biogeochemical cycles in the sea. Plenum, New York, p 179-194 
Graziano LM, La Roche J, Geider RJ (1996) Physiological responses to phosphorus limitation in batch and steadystate cultures of Dunaliella tertiolecta (Chlorophyta): a unique stress-protein as an indicator of phosphate deficiency. J Phycol 32 (in press)

Greene RM, Geider RJ, Falkowski PG (1991) Effect of iron limitation on photosynthesis in a marine diatom. Limnol Oceanogr 36:1772-1782

Greene RM, Geider RJ, Kolber Z, Falkowskj PG (1992) Ironinduced changes in light harvesting and photochemical energy conversion processes in Eukaryotic marine algae. Plant Physiol 100:565-575

Greene RM, Kolber ZS, Swift DG, Tindale NW, Falkowski PG (1994) Physiological limitation of phytoplankton photosynthesis in the Equatorial Pacific determined from natural variability in the quantum yield of fluorescence. Limnol Oceanogr 39:1061-1064

Herzig R, Falkowski PG (1989) Nitrogen limitation in Isochrysis gathana (Hantonhyreae) I Photocynthetirenergy romversion and growth efficiencies. J Phycol 25:462-471

Kana TM, Feiwel NL, Flynn LC (1992) Nitrogen starvation in marine Synechococcus strains: clonal differences in phycobiliprotein breakdown and energy coupling. Mar Ecol Prog Ser 88:75-82

Kolber Z, Barber RT, Coale KH, Fitzwater SE, Greene RM, Johnson KS, Lindley S, Falkowski PG (1994) Iron limitation of phytoplankton photosynthesis in the equatorial Pacific Ocean. Nature 371:145-149

Kolber Z, Falkowski PG (1993) Use of active fluorescence to estimate phytoplankton photosynthesis in situ. Limnol Oceanogr 38:1646-1665

Kolber Z, Wyman KD, Falkowski PG (1990) Natural variability in photosynthetic energy conversion efficiency: a field study in the Gulf of Maine. Limnol Oceanogr 35:72-79

Kolber Z, Zehr J, Falkowski PG (1988) Effects of growth irradiance and nitrogen limitation on photosynthetic energy conversion in photosystem II. Plant Physiol 88:923-929

Legendre L, Yentsch CM (1989) Overview of flow cytometry and image analysis in brological oceanography and limnology. Cytometry 10:501-510

Responsible Subject Editor: S. W. Chisholm, Cambridge, Massachusetts, USA
Li WKW (1994) Primary production of prochlorophytes, cyanobacteria and eukaryotic ultraphytoplankton: measurements from flow cytometric sorting. Limnol Oceanogr 39:169-175

Li WKW (1995) Composition of ultraplankton in the central North Atlantic. Mar Ecol Prog Ser 122:1-8

Morel FMN (1987) Kinetics of nutrient uptake and growth in phytoplankton. J Phycol 23:137-1.50

Olaizola M, Geider RJ, Harrison WG, Graziano LM, Ferrari GM, Schlittenhardt PM (1996) Synoptic study of variations in the fluorescence-based maximum quantum efficiency of photosynthesis across the North Atlantic ocean. Limnol Oceanogr 41:755-765

Olaızola M, Yamamoto HY (1994) Short-term response of the diadinoxanthin cycle and fluorescence yield to high irradiance in Chaetoceros muelleri. J Phycol 30:606-612

Osborne BA, Geider RJ (1986) Effects of nitrate-nitrogen limitation on photosynthesis in the diatom Phaeodactylum trirnrnutum Rohlin (Rarillarinphyreae). Plant Cell Environ 9: $617-625$

Smith RC, Baker KS (1978) The bio-optical state of ocean waters and remote sensing. Limnol Oceanogr 23: $247-259$

Sosik HM, Mitchell BG (1991) Absorption, fluorescence, and quantum yield for growth in nitrogen-limited Dunaliella tertiolecta. Limnol Oceanogr 36:910-921

Strickland JDH, Parsons TR (1972) A practical handbook of seawater analysis, 2nd edn. Bull Fish Res Bd Can 167 . 201-202

Veldhuis MJW, Kraay GW, van Bleijswijk JDL, Baars MA (1996) Seasonal and spatial variability in phytoplankton biomass, productivity and growth in the north-western Indian Ocean (the SW- and NE-monsoon, 1992-1993). J Phycol (in press)

Wu J, Luther GW (1994) Dissolved, colloidal and particulate iron in the water column of the northwest Atlantic Ocean. Limnol Oceanogr 39:11.19-1129

Yentsch CS, Phinney DA (1990) Autofluorescence and Raman scattering in the marine underwater environment. SPIE 1302 Ocean Optıcs X:328-334

Manuscript first received: March 12, 1996

Revised version accepted: June 18, 1996 